ISSN: 2224-0616

Int. J . Agril. Res. Innov. \& Tech. 6 (1): 14-20, June, 2016

Available online at http:// www.ijarit.webs.com

\title{
EFFECTS OF RURAL-URBAN YOUTH MIGRATION ON FARM FAMILIES IN BENUE STATE, NIGERIA
}

\author{
E.N. Mbah" ${ }^{2}$, C.I. Ezeano ${ }^{2}$ and M.O. Agada ${ }^{3}$
}

Received 28 January 2016, Revised 23 May 2016, Accepted 21 June 2016, Published online 30 June 2016

\begin{abstract}
The study was assessed to determine the effects of rural-urban youth migration on farm families in Benue state, Nigeria during November 2014 to June 2015. Interview schedule was used to collect data from a sample of 80 respondents. Data were analyzed using frequency, percentage, mean scores and standard deviation. Results indicate that majority (76.3\%) of the respondents were males, middle aged and married. Major causes of ruralurban youth migration indicated by the respondents include inadequate employment opportunities in rural areas $(M=3.6)$, search for better education $(M=3.5)$, inadequate social infrastructure such as schools $(\mathrm{M}=3.4)$, poor medical care services in rural areas $(\mathrm{M}=3.4)$, looking for money through labour $(\mathrm{M}=3.4)$, apprenticeship programme $(\mathrm{M}=3.2)$, etc. Findings of the study also indicate that reduction of agricultural labour force $(\mathrm{M}=3.5)$, low agricultural productivity $(\mathrm{M}=3.3)$, high cost of labour $(\mathrm{M}=3.3)$, reduction on demand for locally grown foods $(\mathrm{M}=2.9)$, decrease in dependency ratio in the rural areas $(\mathrm{M}=2.7)$, reduction on number of mouths to feed $(\mathrm{M}=2.7)$, among others were major effects of ruralurban youth migration among farm families. The study recommends that Nigerian government should provide adequate physical and social infrastructure in rural areas in order to encourage youths to remain in agriculture, reduce rural-urban youth migration as well as sustain agriculture for enhanced food security.
\end{abstract}

Keywords: Rural Area, Youths, Agriculture, Farm Family, Nigeria

\footnotetext{
${ }^{1}$ Department of Agricultural Extension and Communication, University of Agriculture, Makurdi, Nigeria

${ }^{2}$ Department of Agricultural Economics and Extension, Nnamdi Azikiwe University, Awka, Nigeria

${ }^{3}$ Department of Agricultural Extension and Communication, University of Agriculture, Makurdi, Nigeria

*Corresponding author's email: evanmbah@gmail.com (E.N. Mbah)
}

\section{Introduction}

Agriculture is the major source of income in most rural areas. Evidence has shown that majority of the population in most rural areas are small scale farmers providing food for human consumption and raw materials for export and manufacturing industries. Agriculture also serves as a source of employment to most rural people. The major problems of agricultural development in Nigeria as a whole and among households in Benue state particular include use of crude tools and implements, lack of finance or credit facilities, poor transportation network, inadequate land due to land tenure system, problems of pests and diseases, lack of storage and processing facilities, inadequate agricultural education and extension services, negative attitude of people towards farming due to its low reward, rural youth migration and so on (FAO, 2005).

Rural-urban youth migration can be seen as the physical transnational of young individuals or group of young people from rural areas to urban centers. Rural-urban youth migration is the most important aspect of labour migration because it affects the structures and composition of the population. Rural youth migration as noted by several writers (Olayide, 2009; Lewis, 2004;
Osondu and Ibezim, 2001) have been associated with decline in food production, farming activities, fishing, urban congestion, inadequate infrastructural facilities in urban areas and so on. The decline in food production in developing countries such as Nigeria can be linked to the impart of rural-urban youth migration as well as other variable factors such as economic, soil quality, ecology, climatic conditions, sociocultural setting and poor farm management. With the mass migration of youths from rural to urban areas, only few youths are left behind, consequently the cost of labour has been on the increase. With this trend, most farmers have found it increasable difficult to afford the high cost of labour. Even when some can afford it, labour is readily unavailable because many youths have migrated to cities and most of those left behind may not be interested in agricultural activities. Since more youths migrate to urban areas for better standard of living, many aged people are left to accomplish most tasks associated with farming. There is no doubt that added responsibilities will reduce the productive capacity of the aged ones who already do not have the desired energy to do most farming activities. 
Echebiri (2005) noted that out migration of youths had led to increased participation of older men and women in agricultural production. According to Boque (2002), the supply of labour in agricultural production is usually a function of the size of the population, structure of the population, the preparation of the population entering the labour market and the number of hours, which an individual actually works. Ruralurban youth migration also slows down the pace of development of the rural areas. This therefore raises the following pertinent questions: What are socio-economic characteristics of the respondents? What are the causes of rural-urban youth migration? What are the effects of ruralurban youth migration on agricultural production? What are the strategies for reducing rural-urban youth migration?

Specifically the study sought to:

i. describe socio-economic characteristics of the respondents;

ii. ascertain causes of rural-urban youth migration;

iii. ascertain effects of rural-urban youth migration on agricultural production; and

iv. identify strategies for reducing rural-urban youth migration.

\section{Methodology}

The study was carried out in Benue State, Nigeria during November 2014-J une 2015 because of devastating effects of rural-urban youth migration on agricultural productivity. The state has three agricultural zones, namely; A, B, and C. Benue state has a land area of $2,882 \mathrm{~km}^{2}$ with a population of 4,253,641 people. Map of the study area is shown in figure 1 below. It has twenty three (23) local government areas. Benue State lies within the lower river Benue in the middle belt region of Nigeria. Its geographic coordinates are longitude $7^{\circ} 47^{\prime}$ and $10^{\circ} 0^{\prime}$ East. Latitude $6^{\circ}$ $25^{\prime}$ and $8^{\circ} 8^{\prime}$ North; and shares boundaries with five other states namely; Nasarawa to the north, Taraba to the east, Cross-River to the south, Enugu to the south-west and Kogi State to the west. The state also shares a common boundary with the Republic of Cameroon on the south-east. Agriculture is the mainstay of the inhabitants engaging over $75 \%$ of the population. The State is the nation's acclaimed food basket because of its rich agricultural produce, which include yam, rice, beans, cassava, sweet-potato, maize, soybean, sorghum, millet, sesame, cocoyam, etc. The state accounts for over $70 \%$ of Nigeria's soybean production. Tree crops such as mangoes and oranges of various species are also produced in commercial quantity. They also rear a wide range of livestock such as pigs, goats, sheep and chicken. Many of the inhabitants also engage in trading, while a reasonable number of them are civil servants.

Benue state is made up of three zones namely; A, $\mathrm{B}$ and $\mathrm{C}$. Zone B was purposively selected for the study. Guma and Makurdi Local Government Areas were selected from the zone using simple random sampling technique. Four communities were selected from each of the local government areas, while ten (10) heads of households were selected from each of the communities, giving eighty (80) respondents used for the study.

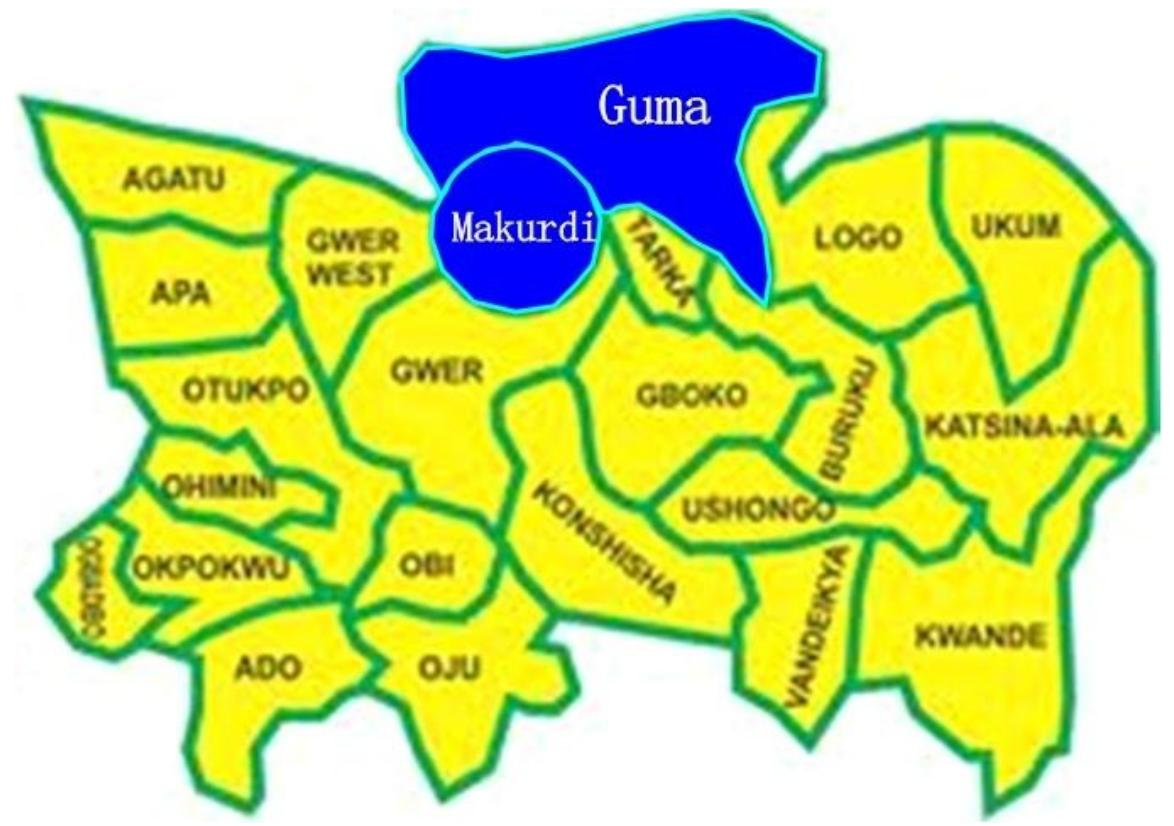

Fig. 1. Map of Benue state showing the study area

Data were collected using interview was used for literate farmers. The interview schedule/ questionnaire. Interview schedule was schedule/questionnaire was divided into four used for illiterate farmers, while questionnaire sections (A-D) based on the specific objectives of 
the study. Section A provided information on socio-economic characteristics of the respondents. The second section centered on causes of rural-urban youth migration. Effects of rural-urban migration on agricultural production were the focus of section C, while section D highlighted strategies for reducing rural-urban youth migration. Frequency, percentage, mean scores and standard deviation were used for data analysis.

\section{Results and Discussion} Socio-economic characteristics of the
respondents

Sex

Majority (76.3\%) of the respondents were males, while $23.3 \%$ were females. This implies that most of the farm families were dominated by males and there may be tendency for them to migrate to urban centers in search of white collar jobs, thereby leaving farming activities to be done by female members of the households.

\section{Age (y ears)}

Data in Table 1 indicate that about $26 \%$ of the respondents were within the age of 31-40 years, $23.7 \%$ were aged between 41 and 50 years, while about $21 \%$ were aged $51-60$ years, among others. It implies that the respondents were middle aged and in their productive and are likely to have the opportunity to migrate to urban centers. The findings disagree with Bergelliot (2006) who stated that the incidence of migration is highest among the most productive age group of 15-30 years.

\section{Marital status}

Majority (91.2\%) of the respondents were married, while $8.8 \%$ were single. This implies that there is greater involvement of married people in farming activities in order to ensure household food security. This is in agreement with Adegboye et al. (2008) who stated that involvement of the married people in farming activities is because of the need to supplement family means of livelihood.

\section{Level of education (years)}

Data in Table 1 indicate that $36.3 \%$ had no formal education, $28.8 \%$ had secondary education, while $23.7 \%$ attended primary education, among others. It shows that the respondents were literate enough. Okojie (2002) observed that the more educated a farmer is the more likely he adopts an innovation.

\section{Household size (numbers)}

Table 1 also indicate that $30.0 \%$ of the respondents had a household size of 6-10 persons, about $24.0 \%$ had a household size of $11-$ 15 persons, while $20.0 \%$ had a household size of between 1 and 5 persons. This indicates that the respondents had a large household size, which could serve as a source of labour on family farms.

\section{Farm size (hectares)}

Entries in Table 1 also show that $51.3 \%$ had a farm size of 2-4 hectares, while $26.3 \%$ had a farm size of less than 2 hectares, among others. This implies that the respondents practice small-scale farming because of fragmented land holdings.

\section{Farming experience (years)}

A greater percentage (57.6\%) of the respondents had a farming experience of 20 years and above, while $30.0 \%$ had a farming experience of $11-20$ years, among others. This indicates that the respondents have been farming for a long period. This could be attributed to the fact that the study area is an agrarian community.

\section{Membership of agricultural organization}

About $69 \%$ of the respondents belonged to one form of agricultural organization or the other, while $31.2 \%$ did not belong to any agricultural organization (Table 1). It shows that many of the respondents were members of agricultural organizations. This could serve as an avenue for sourcing information as well as accessing credits from the government to improve production.

\section{Type of organization}

Results in Table 1 show that $45.5 \%$ were members of Fadama user group, $29.1 \%$ belonged to farmer group, while $25.5 \%$ of them were members of cooperative society. The ability to be a member of an agricultural organization helps in dissemination of information as well as diffusion of innovations for increased productivity.

\section{Major occupation}

Data in Table 1 revealed that $45.0 \%$ of the respondents had farming as a major occupation, about 38\% engaged in petty trading, while $12.5 \%$ were civil servants, among others. This indicates that the major source of livelihood for the respondents was farming.

\section{Contact with extension agents}

A greater percentage (51.2\%) of the respondents had no contact with extension agents, while 48.8\% had contact with extension agents (Table 1). This implies that extension agents did not have adequate coverage in the study area; hence, information disseminated through them may not be available to the farmers.

\section{Number of visits by extension agent}

Data in Table 1 show that majority (64.1\%) of the respondents had 1-5 times of visits by extension agents, $15.4 \%$ had between 11 and 15 number of visits by extension agents, among others. This implies that the farmers did not have adequate contact with the extension agents. 
Mbah et al. (2016) Effects of rural-urban youth migration on farm families in Benue state, Nigeria

Table 1. Distribution of respondents according to socio-economic characteristics ( $\mathrm{n}=80$ )

\begin{tabular}{|c|c|c|}
\hline Socio-economic characteristics & Frequency & Percentage \\
\hline Sex & & \\
\hline Male & 61 & $\begin{array}{l}76.3 \\
237\end{array}$ \\
\hline $\begin{array}{l}\text { Female } \\
\text { Total }\end{array}$ & $\begin{array}{l}19 \\
80\end{array}$ & $\begin{aligned} 23.1 \\
100.0\end{aligned}$ \\
\hline Age (years) & & \\
\hline$\leq 20$ & 3 & 3.8 \\
\hline $31-40$ & 21 & 263 \\
\hline $41-50$ & 19 & 23.7 \\
\hline $51-60$ & 17 & 21.3 \\
\hline Above 60 & 5 & 6.1 \\
\hline Total & 80 & 100.0 \\
\hline Marital status & & \\
\hline Single & 7 & 8.8 \\
\hline Married & 73 & 91.2 \\
\hline $\begin{array}{l}\text { Total } \\
\text { Level of Education (vears) }\end{array}$ & 80 & 100.0 \\
\hline $\begin{array}{l}\text { Level of Education (years) } \\
\text { No formal education }\end{array}$ & & \\
\hline Primary education & 29 & 36.3 \\
\hline Secondary education & $\frac{19}{23}$ & 23.7 \\
\hline Tertiary education & 9 & 28.8 \\
\hline Total & 80 & $\begin{array}{l}11.2 \\
100.0\end{array}$ \\
\hline Household size (numbers) & & \\
\hline $1-5$ & 16 & 20.0 \\
\hline $6-10$ & 24 & 30.0 \\
\hline $11-15$ & 19 & 23.7 \\
\hline $16-20$ & 13 & 16.3 \\
\hline Äbove 20 & 8 & 10.0 \\
\hline Total & 80 & 100.0 \\
\hline Farm size (hectares) & & \\
\hline $\begin{array}{l}<2 \\
2-4\end{array}$ & $\begin{array}{l}21 \\
41\end{array}$ & $\begin{array}{l}26.3 \\
513\end{array}$ \\
\hline $\begin{array}{l}2-4 \\
5-7\end{array}$ & 7 & $\begin{array}{l}5.3 .3 \\
8.8\end{array}$ \\
\hline $8-10$ & 5 & 6.2 \\
\hline Above 10 & 6 & 7.4 \\
\hline Total & 80 & 100 \\
\hline Farming experience (years) & & \\
\hline $\begin{array}{l}1-5 \\
6-10\end{array}$ & $\begin{array}{l}4 \\
6\end{array}$ & 5.0 \\
\hline $11-15$ & 12 & 15.4 \\
\hline $16-20$ & 12 & 15.0 \\
\hline Above 20 & 46 & 57.6 \\
\hline Total & 80 & 100 \\
\hline Membership of agricultural organization & & \\
\hline Yes & 55 & 68.8 \\
\hline No & 25 & 31.2 \\
\hline Total & 80 & 100 \\
\hline Type of organization & & \\
\hline Fadama user group & 25 & 45.5 \\
\hline $\begin{array}{l}\text { Cooperative society } \\
\text { Farmer qroup }\end{array}$ & $\begin{array}{l}14 \\
16\end{array}$ & $\begin{array}{l}25.5 \\
291\end{array}$ \\
\hline $\begin{array}{l}\text { Farmer group } \\
\text { Total }\end{array}$ & 55 & $\begin{array}{l}29.1 \\
100\end{array}$ \\
\hline Major occupation & & \\
\hline Farming & 36 & 45.0 \\
\hline Teaching & 4 & 5.0 \\
\hline Petty trading & 30 & 37.5 \\
\hline Civil service & 10 & 12.5 \\
\hline Total & 80 & 100 \\
\hline $\begin{array}{l}\text { Contact with extension agents } \\
\text { Yes }\end{array}$ & 39 & 488 \\
\hline No & 41 & 51.2 \\
\hline Total & 80 & 100 \\
\hline $\begin{array}{l}\text { Number of visits } \\
1-5\end{array}$ & 25 & 641 \\
\hline 6-10 & 5 & 12.8 \\
\hline $11-15$ & 6 & 15.4 \\
\hline Above 15 & 3 & 7.7 \\
\hline Total & 39 & 100 \\
\hline
\end{tabular}




\section{Causes of rural-urban youth migration}

The major causes of rural-urban youth migration indicated by the respondents include inadequate employment opportunities in rural areas $(M=3.6)$, search for better education $(M=3.5)$, inadequate social infrastructure such as schools $(\mathrm{M}=3.4)$, poor medical care services in rural areas $(\mathrm{M}=3.4)$, obtaining money through labour
$(\mathrm{M}=3.4)$, apprenticeship programme $(\mathrm{M}=3.2)$, better transport facilities in the urban areas $((\mathrm{M}=3.2)$, joining family members in the city $(M=3.2)$, better housing in the city $(M=3.1)$, change of environment ( $\mathrm{M}=3.1)$, displacement as a result of communal crisis $(\mathrm{M}=3.0)$, social status of one's parents $(\mathrm{M}=2.8)$, among others.

Table 2. Mean score of causes of rural-urban youth migration

\begin{tabular}{lcc}
\hline Causes & Mean scores & Standard deviation \\
\hline Inadequate employment opportunities in rural areas & 3.6 & 0.76 \\
Search for better education & 3.5 & 0.74 \\
Inadequate social infrastructure such as schools & 3.4 & 0.74 \\
Famine and drought resulting in hunger & 2.5 & 1.00 \\
Lack of interest in farming & 2.8 & 1.11 \\
Poor medical care services in rural areas & 3.4 & 0.83 \\
Apprenticeship programmes & 3.2 & 0.72 \\
Natural disasters such as flood and fire outbreak & 2.4 & 0.98 \\
Better housing in the city & 3.1 & 0.87 \\
Change of environment & 3.1 & 0.80 \\
Escape from punishment as a result of crime committed & 2.6 & 1.01 \\
Poor chances of marrying & 2.1 & 0.93 \\
Inadequate physical infrastructure such as good roads and & 3.2 & 0.94 \\
electricity & & \\
Social status of one's parents & 2.8 & 0.99 \\
Better transport facilities in the urban areas & 3.2 & 0.91 \\
Join family members in the city & 3.2 & 0.83 \\
Obtaining money through labour & 3.2 & 0.76 \\
Displacement as a result of communal crises & 3.0 & 0.84 \\
Desire for more political or religious power & 2.6 & 0.99 \\
\hline
\end{tabular}

\section{Effects of rural-urban youth migration}

Major effects of rural-urban youth migration indicated by the respondents include contribute to reduction in agricultural labour force $(\mathrm{M}=3.5)$, low agricultural productivity $(\mathrm{M}=3.3)$, high cost of labour $(\mathrm{M}=3.3)$, farm work becomes tedious $(\mathrm{M}=3.3)$, reduction of household annual income, $(\mathrm{M}=3.2)$, poor standard of living $(\mathrm{M}=3.2)$, leads to diversification into non-farm $(\mathrm{M}=3.1)$, unavailability of farm labour $(M=3.0)$, farm work is mostly done by aged parent $(\mathrm{M}=3.0)$, reduces demand on locally grown foods ( $\mathrm{M}=2.9)$, reduces formation of groups and cooperative society $(\mathrm{M}=2.9)$, decreases the dependency ratio in the rural areas $(\mathrm{M}=2.7)$, reduces number of mouths to feed $(\mathrm{M}=2.7)$, among others. This leads to a heavy drain on the supply of rural family labour and in addition pulls out the individuals who are essential elements for agricultural development programmes and also hinders rural productivity and growth of agriculture sector.

Table 3. Mean scores of effects of rural-urban youth migration among farm families

\begin{tabular}{lcc}
\hline Effects & Mean scores & Standard deviation \\
\hline Reduction in agricultural labour force & 3.5 & 0.67 \\
\hline Low agricultural productivity & 3.3 & 0.69 \\
Decreases the dependency ratio in rural areas & 2.7 & 0.95 \\
Reduces number of mouths to feed & 2.7 & 0.97 \\
Reduces demand on locally grown feeds & 2.9 & 0.91 \\
Reduces formation of groups and cooperative societies & 2.9 & 0.97 \\
among youths. & & \\
Farm work is mostly done by aged parents & 3.0 & 1.04 \\
High cost of labour & 3.3 & 0.80 \\
Farm work becomes tedious & 3.3 & 0.95 \\
Unavailability of farm labour & 3.0 & 0.97 \\
Food insecurity in households & 2.9 & 0.88 \\
Poor yield of crops as a result of farm input & 3.1 & 1.03 \\
Leads to poverty among farm families & 3.0 & 0.97 \\
Reduction of household annual income & 3.2 & 0.79 \\
Poor standard of living & 3.2 & 0.98 \\
Leads to diversification into non-farm occupation & 3.1 & 0.79 \\
\hline
\end{tabular}
ii. 
Strategies for reducing rural-urban youth migration

Data in Table 4 revealed the strategies for reducing rural-urban youth migration which include provision of basic amenities such as schools, pipe borne water, electricity $(\mathrm{M}=3.9)$, establishment of vocational training centers for skill acquisition ( $\mathrm{M}=3.7)$, use of improved modern technologies such as farm implements $(\mathrm{M}=3.6)$, regular and timely provision of farm input such as fertilizers and agro-chemicals $(\mathrm{M}=3.6)$, provision of incentives such as microcredits for youths in agriculture $(\mathrm{M}=3.5)$, empowering and integrating rural youths into agricultural based activities $(\mathrm{M}=3.5)$, establishment of advocacy programmes such as youths employment in agriculture to encourage them ( $M=3.5)$, encouraging formation of groups and societies such as young farmers clubs and cooperative societies for easy access to loans $(\mathrm{M}=3.5)$. Others are provision of improved varieties of crops and breeds of livestock $(\mathrm{M}=3.5)$, provision of labour saving devices for easy farm operations $(\mathrm{M}=3.5)$, establishment of agroprocessing centres for value addition of farm produce $(M=3.5)$, subsidizing prices of farm inputs such as fertilizers, herbicides, pesticides etc. $(M=3.5)$, establishment of bank of agriculture in rural areas for easy access to loans $(\mathrm{M}=3.5)$, use of improved method of farming in order to attract youths $(\mathrm{M}=3.4)$, establishment of agroallied industries in rural areas ( $\mathrm{M}=3.4)$, making agricultural science a compulsory subject in primary and secondary schools to promote interests of youths in agriculture $(M=3.1)$.

Table 4. Mean scores of strategies for reducing rural-urban youth migration

\begin{tabular}{|c|c|c|}
\hline Strategies & Mean scores & Standard deviation \\
\hline $\begin{array}{l}\text { Provision of basic amenities such as schools, pipe borne } \\
\text { water and electricity }\end{array}$ & 3.9 & 0.30 \\
\hline $\begin{array}{l}\text { Establishment of vocational training centers for skill } \\
\text { acquisition }\end{array}$ & 3.7 & 0.51 \\
\hline $\begin{array}{l}\text { Provision of incentives such as microcredit for youths in } \\
\text { agriculture }\end{array}$ & 3.5 & 0.62 \\
\hline $\begin{array}{l}\text { Empowering and integrating rural youths into } \\
\text { agricultural-based activities }\end{array}$ & 3.5 & 0.59 \\
\hline $\begin{array}{l}\text { Establishment of advocacy programme such as youth } \\
\text { employment in agriculture }\end{array}$ & 3.5 & 0.57 \\
\hline $\begin{array}{l}\text { Encouraging formation of groups and societies such as } \\
\text { young farmers clubs and cooperative societies for easy } \\
\text { access to loans }\end{array}$ & 3.5 & 0.75 \\
\hline $\begin{array}{l}\text { Provision of improved varieties of crops and breeds of } \\
\text { livestock }\end{array}$ & 3.5 & 0.66 \\
\hline $\begin{array}{l}\text { Use of improved modern technologies such as farm } \\
\text { implements }\end{array}$ & 3.6 & 0.65 \\
\hline $\begin{array}{l}\text { Provision of labour saving devices for easy farm } \\
\text { operation }\end{array}$ & 3.5 & 0.67 \\
\hline $\begin{array}{l}\text { Establishment of agro-processing centres for value of } \\
\text { farm produce }\end{array}$ & 3.6 & 0.69 \\
\hline $\begin{array}{l}\text { Regular and timely provision of farm inputs such as } \\
\text { fertilizers and agro-chemical }\end{array}$ & 3.6 & 0.58 \\
\hline $\begin{array}{l}\text { Subsidizing prices of farm inputs such as fertilizers, } \\
\text { herbicide and pesticide etc. }\end{array}$ & 3.5 & 0.69 \\
\hline $\begin{array}{l}\text { Use of improved method of farming in order to attract } \\
\text { youths }\end{array}$ & 3.4 & 0.72 \\
\hline $\begin{array}{l}\text { Making agricultural science a compulsory subject in } \\
\text { primary and secondary schools to promote interests of } \\
\text { youths in agriculture } \\
\text { Establishment of agro-allied industries in the rural areas }\end{array}$ & 3.1 & 0.88 \\
\hline $\begin{array}{l}\text { Establishing of Bank of Agriculture in rural areas for } \\
\text { easy access to loans }\end{array}$ & 3.5 & 0.73 \\
\hline
\end{tabular}

\section{Conclusion and Recommendations}

The survey discovered that most of the respondents were males, married, middle aged, having a farming experience of about 22 years. Majority of the respondents belonged to one type of agricultural organization or the other. Causes of rural-urban youth migration were inadequate employment opportunities in rural areas, search for better education, inadequate social infrastructure such as schools, poor medical care services in rural areas, etc. Major effects of rural- 
urban youth migration as indicated by the respondents were reduction in agricultural labour force, low agricultural productivity, high cost of labour, farm work becomes tedious, reduction of household annual income, farm work mostly done by aged parent, unavailability of farm labour, food insecurity in households, among others. The study recommends that adequate physical and social infrastructures such as good roads, electricity, schools and hospitals should be put in place in rural areas by Nigerian government in order to encourage youths to remain in agriculture, reduce rural-urban youth migration as well as sustain agriculture for enhanced food security.

\section{References}

Adegboye, M.A, Eniolorunda, P.A and Awe, O.A. 2008. Constraints to effective fertilizer utilization by maize farmers in Ido local government area, Oyo State. In: Proceedings of 42 nd Annual Conference of Agricultural Society of Nigeria, p. 871.

Bergelliot, A. 2006. Improving agriculture through research and extension approach. J. Agril. Res. Poli. 2(5): 14-18.
Boque, K. 2002. Effects of migration of farmers on sustainable livelihood in Nigeria. IOSR J. Business \& Manage 3(3): 30.

Echebiri, K. 2005. Ties to origin, remittances and mobility: Evidence from rural-urban migration areas in Nigeria. J. Dev. Areas 20: 339-356.

FAO. 2005. Migration and rural employment. Proceeding of round table on migration and rural employment in conjunction with the thirtieth section of FAO Governing Council. Food and Agriculture Organization, Rome Italy. pp. 32-35.

Lewis, F.A. 2004. Dual labour market theory. J. Dev. Econ. 2(2):165-187.

Okojie, C. 2002. Gender and education as determinants of household poverty in Nigeria. In: Hoven, R.V. and Sherrocks, A. (Eds.), Perspective of growth and poverty, pp. 262-302.

Olayide, D.W. 2009. Rural-urban migration and agriculture development in Nigeria. Art Soc. Sci. Int. Res. J. 1: 30.

Osondu, C.K. and Ibezim C.O. 2001. The impact of rural-urban migration on plantation Agriculture in the Niger-Delta Region, Nigeria. J . Rural Social Sci. 1:20. 